\title{
Perancangan Sistem Manajemen Laboratorium untuk Mendukung Pengembangan Smart Campus
}

\author{
Emmy Wahyuningtyas ${ }^{1}$, Shofiya Syidada ${ }^{1}$, Firman Hadi ${ }^{1}$ \\ ${ }^{1}$ Program Studi Teknik Informatika - Universitas Wijaya Kusuma Surabaya \\ Email:emmy@uwks.ac.id, shofiya@uwk.ac.id, firmanpratama@uwk.ac.id
}

(artikel diterima: 12 Desember 2020; artikel diterima: 28 Februari 2021 )

\begin{abstract}
ABSTRAK
Laboratorium sebagai tempat untuk melaksanakan berbagai kegiatan akademik seperti riset dan praktikum yang diharapkan dapat berfungsi secara optimal. Peran laboratorium menjadi salah satu faktor kunci keberhasilan penyelenggaraan aktivitas akademik oleh sebuah program studi, untuk itu laboratorium harus dikelola dengan baik mengikuti standar mutu yang telah ditetapkan oleh institusi. Penelitian ini bertujuan untuk membuat perancangan sistem manajemen laboratorium pada Program Studi Teknik Informatika Universitas Wijaya Kusuma Surabaya, khususnya untuk menangani kegiatan praktikum. Penelitian dilakukan dalam beberapa tahap, menggunakan metode pengembangan berbasis obyek yaitu pengumpulan data, analisis kebutuhan dan perancangan sistem menggunakan pemodelan Unified Modelling Language (UML). Hasil penelitian berupa use case scenario, activity diagram, sequence diagram dan class diagram yang diharapkan dapat menjadi referensi bagi pengembangan sistem selanjutnya.
\end{abstract}

Kata kunci: analisa, perancangan, manajemen, laboratorium, praktikum, UML

\begin{abstract}
The laboratory is a place to carry out various academic activities such as research and practice which are expected to function optimally. The role of the laboratory is one of the key factors in the successful implementation of academic activities by a study program, for this reason the laboratory must be well managed according to the quality standards set by the institution. This study aims to design a laboratory management system in the Informatics Engineering Study Program at Wijaya Kusuma University, Surabaya, especially to handle practical activities. The research was conducted in several stages, using object-based development methods, namely data collection, requirements analysis and system design using Unified Modeling Language (UML) modeling. The results of the research are in the form of use case scenarios, activity diagrams, sequence diagrams and class diagrams which are expected to be a reference for further system development.
\end{abstract}

Keywords: analysis, design, lab management, lab session, UML

\section{PENDAHULUAN}

Salah satu pembelajaran di luar kelas menjadi hal yang sudah semestinya dikelola dengan baik. Menurut ( Badan Pengembangan dan Pembinaan Bahasa Kemdikbud RI, 2016) disebutkan bahwa tujuan praktikum untuk melaksanakan teori serta mengujinya dalam keadaan nyata.

Melalui pembelajaran praktikum diharapkan mahasiswa mampu mengaplikasikan teori secara langsung dalam bentuk beragam tugas mandiri dan kelompok.

Praktikum merupakan mata kuliah wajib yang harus ditempuh bagi mahasiswa dan tersebar ke dalam beberapa semester. Pelaksanaan praktikum sendiri berada di bawah manajemen masing-masing laboratorium (lab) yang dikepalai seorang kepala 
laboratorium (Kalab). Setiap lab membawahi beberapa mata praktikum yang masing-masing diselenggarakan dalam beberapa sesi, pembagian sesi ini guna memenuhi kebutuhan praktikum seluruh praktikan dengan memperhatikan kapasitas lab. Pelaksanaan praktikum sendiri melibatkan beberapa pihak antara lain kalab sebagai penanggungjawab seluruh mata praktikum yang berada di bawahnya, dosen pengampu sebagai penanggung jawab masing-masing mata praktikum, asisten bertugas membantu dosen pengampu dalam pelaksanaannya serta praktikan yang semuanya saling terkait mulai persiapan hingga pelaporan kegiatan praktikum. Merujuk pada Sistem Penjaminan Mutu Internal (SPMI) bahwa setiap kegiatan pembelajaran harus mengikuti siklus Penetapan, Pelaksanaan, Evaluasi, Pengendalian dan Peningkatan (PPEPP), maka kegiatan pembelajaran praktikum yang ada di Program Studi Teknik Informatika Universitas Wijaya Kusuma Surabaya seharusnya mengikuti siklus tersebut. Namun saat ini, praktikum belum dikelola secara terpadu dengan sistem akademik utama sehingga masih terdapat beberapa hal terkait administratif yang ditangani secara parsial bahkan manual. Perencanaan praktikum dimulai sejak mahasiswa memprogramnya pada Kartu Rencana Studi (KRS) secara online. Data tersebut dihimpun per mata praktikum menjadi data presensi peserta praktikum per kelas, namun hal ini menjadi tidak cocok dengan peserta praktikum riil per sesi mengingat kapasitas kelas yang tercantum pada KRS online tidak sama dengan kapasitas lab. Hal ini menjadi kendala bagi program studi dalam mengelola data praktikan karena masih harus membagi data praktikan secara manual ke dalam sesi praktikum riil. Selain itu untuk proses pembayaran praktikum yang harus dilakukan di awal semester, belum dapat dimunculkan nominal tagihan secara otomatis berdasarkan data KRS. Mahasiswa masih harus mendaftar lagi pada bagian tata usaha fakultas untuk didaftarkan pada sistem pembayaran tersendiri, hal ini dirasa cukup rumit karena masih memerlukan otorisasi dari dosen pendamping akademik.

Proses monitoring pelaksanaan praktikum masih dilakukan secara manual hingga pelaporan tugas dan penilaian yang masih terpisah-pisah per kelompok praktikum. Proses rekrut dan penyimpanan data asisten belum terakomodasi dalam sistem sehingga penugasannya pun masih belum obyektif.

Bentuk pelaporan kegiatan praktikum belum standar dan terdokumentasi dalam sistem sehingga sulit untuk menemukan kembali histori data praktikum yang telah lampau. Hal ini juga terjadi saat dibutuhkan data inventaris lab untuk kepentingan pengambilan keputusan oleh pimpinan program studi dikarenakan penyajian data atau informasi yang tidak available dan qualified.

Kendala lain adalah belum adanya sistem yang memfasilitasi pimpinan program studi untuk dapat secara langsung mengakses data dan informasi tentang kegiatan yang dilaksanakan di semua lab secara terpadu, guna mendukung kegiatan audit mutu internal yang dilakukan oleh Badan Penjaminan Mutu di tingkat universitas.

Dalam penelitian ini, dirancang suatu sistem manajemen laboratorium khususnya untuk menangani pembelajaran praktikum, yang diharapkan dapat menjadi rujukan bagi pengembangan aplikasi selanjutnya, sehingga dapat mendukung operasional pelaksanaan praktikum di lingkup Program Studi Teknik Informatika Universitas Wijaya Kusuma Surabaya agar menjadi efektif dan efisien. 


\section{TINJAUAN PUSTAKA}

\section{A. Praktikum}

(Lunetta, Hofstein, \& Clough, 2007) menyatakan bahwa peserta didik mendapat pengalaman belajar dengan berinteraksi dengan mengamati dan memahami dunia alam. Pustaka lain menyatakan bahwa dalam praktikum peserta didik diberikan kesempatan untuk menemukan serta membuktian fakta yang penting untuk diketahui (Zain, 2006). (Winataputra, 2007) berpendapat bahwa dalam praktikum peserta didik secara aktif menyusun, mengalami dan membuktikan sendiri mengenai teori yang telah didapatkan.

\section{B. Laboratorium Komputer}

Basori dalam (Supianto, 2016) mengemukakan bahwa laboratorium komputer wajib memiliki standar tentang struktur organisasi yang minimal terdiri dari kepala laboratorium, teknisi serta tenaga laboran. Selain itu tata ruang harus terpisah antara tempat aktivitas, tempat penyimpanan, dan tempat pengelolaan, serta memiliki daya tampung yang memadai. Peralatan pembelajaran pratikum harus tersedia memadai dan berfungsi dengan baik serta tersimpan dengan aman, dilengkapi dengan petunjuk operasional dan prosedur penggunaan yang mudah dipahami. Tata tertib laboratorium wajib ada untuk mengatur proses dan layanan. Perihal keselamatan dan keamanan laboratorium juga wajib dipenuhi dengan tersedianya peralatan P3K, pemadam kebakaran, dan alat keselamatan kerja lainnya beserta prosedur nya. Pendapat lain menyatakan bahwa laboratorium komputer sebagai tempat pelaksanaan praktikum untuk Teknologi Informasi dan Komunikasi (Ibrahim, 2003). Sedangkan menurut (Soedirman, 2011) di dalam laboratorium komputer terjadi proses belajar yang bersifat praktik tentang materi computer.

\section{Perancangan Berorientasi Obyek}

Perancangan sistem adalah proses yang menjelaskan bagaimana komponen system akan bekerja dan saling berinteraksi untuk memberikan solusi yang dapat diimplementasikan (Satzinger, Jackson, \& Burd, 2011).

\section{Unified Modelling Language}

(Nugroho, Rekayasa Perangkat Lunak Berbasis Objek dengan Metode USDP, 2010) menyatakan bahwa UML merupakan metodologi kolaborasi antara metoda-metoda Object Oriented Software Enggineering (OOSE), Booch, Object Modeling Technique (OMT), serta beberapa metode lainnya. Dinyatakan juga bahwa metode ini paling sering digunakan sebagai alat bantu analisis dan perancangan sistem untuk mengadaptasi maraknya pemakaian bahasa pemrograman berorientasi objek. Pada pada bukunya yang lain disebutkan bahwa UML sebagai bahasa pemodelan untuk perangkat lunak atau sistem yang berorientasi obyek, dimana pemodelan ini digunakan untuk menyederhanakan masalah sedemikian rupa sehingga mudah dipahami dan dipelajari.

Dalam bukunya (Booch, Rumbaugh, \& Jacobson, 2005) menyatakan bahwa UML merupakan bahasa yang digunakan untuk membantu proses perancangan perangkat lunak serta pembuatan dokumentasinya.

Menurut (Yanuarti, 2017) Diagram Kasus Penggunaan dapat membantu menggambarkan kebutuhan sistem dari sudut pandang pengguna serta pola perilaku sistem. Selain itu diagram tersebut memvisualisasikan interaksi antara sistem dan eksternal sistem atau 
interaksi antara sistem dengan aktor yang terlibat. Tentang Diagram aktivitas, dalam buku tersebut dinyatakan bahwa ia digunakan untuk menggambarkan aktivitas apa saja, bagaimana setiap aliran aktivitas dimulai, putusan yang mungkin terjadi, dan bagaimana sebuah aktivitas berakhir. Diagram ini juga menggambarkan aktivitas yang berjalan paralel yang mungkin terjadi pada beberapa eksekusi. Melalui diagram aktivitas digambarkan setiap proses dan jalur nya mulai tingkat atas secara umum.

Menurut (Putra \& Andriani, 2019) proses definisi dari struktur kelas-kelas yang akan dibangun untuk sebuah sistem digambarkan secara detil menggunakan diagram kelas. Diagram ini terdiri dari atribut dan operasi yang menunjukkan kesesuaian relasi antara hasil rancangan dan sistem nya. Sementara mengenai diagram urutan, dalam buku ini dinyatakan bahwa diagram tersebut menggambarkan perilaku obyek pada kasus penggunaan dengan mendeskripsikan waktu hidup objek dan pesan yang dikirimkan dan diterima antar objek. Dalam diagram urutan ini minimal terdapat sejumlah urutan yang sama jumlahnya pada diagram kasus penggunaan sehingga semakin banyak kasus penggunaan yang berhasil terdefinisi, maka diagram urutan yang dibuat juga semakin banyak.

\section{METODE PENELITIAN}

Pada tahap ini dilakukan langkahlangkah sebagai berikut :

\section{A. Pengumpulan Data}

Data yang digunakan dalam penelitian ini diperoleh melalui pengamatan lapang yaitu dengan mengamati perjalanan data yang dibutuhkan untuk kegiatan praktikum mulai perencanaan sampai pelaporan di akhir semester. Selain itu kajian dokumen juga dilakukan untuk mengkonfirmasi segala bentuk data yang didapatkan pada pengamatan lapang. Selain itu studi pustaka dilakukan guna mendapatkan literatur yang dibutuhkan sebagai penunjang penelitian.

\section{B. Analisis Kebutuhan}

Berdasarkan data yang telah dihimpun pada tahap sebelumnya, selanjutnya peneliti melakukan analisis kebutuhan fungsional untuk sistem manajemen laboratorium namun dibatasi hanya yang terkait dengan praktikum saja. Area yang menjadi sasaran pada tahap ini antara lain perencanaan praktikum meliputi pembuatan jadwal dan setup praktikum, pelaksanaan praktikum meliputi monitoring dan entry nilai.

Pemodelan menggunakan UML guna menjelaskan kebutuhan data dan informasi yang dihasilkan, menggambarkan basis data serta proses yang dijalankan.

\section{Perancangan Sistem}

Pada tahap ini dilakukan perancangan sistem secara rinci berdasarkan dokumen hasil analisis pada tahap sebelumnya. Rancangan sistem berupa gambaran rinci setiap aktivitas sistem yang baru beserta rancangan basis datanya. Digunakan use case diagram dan class diagram untuk memodelkan sistem yang diusulkan agar dokumentasi sistem dapat di deliver dengan mudah kepada pihak terkait.

\section{HASIL DAN PEMBAHASAN}

Beberapa deliverables yang dihasilkan pada penelitian ini dikelompokkan kedalam dua bagian yaitu bagian perencanaan praktikum dan pelaksanaan praktikum, yang pada masing-masing bagian terdiri dari use case scenario, activity diagram dan sequence diagram. 


\subsection{Perencanaan Praktikum}

Bagian ini meliputi setup praktikum dan pembuatan jadwal. Tabel 1 menunjukkan skenario setup praktikum yang dilakukan oleh dosen pengampu.

Tabel 1. Skenario Setup Praktikum

\begin{tabular}{|c|c|c|c|}
\hline \multirow{2}{*}{\multicolumn{2}{|c|}{$\begin{array}{l}\text { Use case name : } \\
\text { Area : }\end{array}$}} & Set up Praktikum & UniqueID : \\
\hline & & SITRANS & \\
\hline \multicolumn{2}{|c|}{ Actor(s) : } & Dosen & \\
\hline \multicolumn{2}{|c|}{ Description } & \multicolumn{2}{|c|}{$\begin{array}{l}\text { Mempersiapkan MK transitoris praktikum yang } \\
\text { akan dilaksanakan pada semester berjalan yang } \\
\text { meliputi pengisian RPS dan modul praktikum }\end{array}$} \\
\hline \multicolumn{2}{|c|}{ Triggering Event : } & \multicolumn{2}{|c|}{ Awal semester } \\
\hline \multicolumn{2}{|c|}{ Trigger Type : } & External & Temporal \\
\hline \multicolumn{3}{|c|}{ Step Performed (Main Path) } & Information for Steps \\
\hline 1. & \multicolumn{2}{|c|}{$\begin{array}{l}\text { Dosen login pada sub system } \\
\text { praktikum }\end{array}$} & $\begin{array}{l}\text { Username, password, hak } \\
\text { akses dosen }\end{array}$ \\
\hline 2. & \multicolumn{2}{|c|}{$\begin{array}{l}\text { Dosen memilih praktikum yang } \\
\text { akan dibuat RPS dan modulnya }\end{array}$} & $\begin{array}{l}\text { Data praktikum pada } \\
\text { semester berjalan }\end{array}$ \\
\hline 3. & \multicolumn{2}{|c|}{ Dosen membuat RPS } & Data praktikum \\
\hline 4. & \multicolumn{2}{|c|}{ Dosen membuat modul } & Data materi praktikum \\
\hline \multicolumn{2}{|c|}{ Preconditions : } & \multicolumn{2}{|c|}{$\begin{array}{l}\text { Data praktikum yang dibuka pada semester berjalan } \\
\text { telah ditetapkan }\end{array}$} \\
\hline \multicolumn{2}{|c|}{ Postconditions : } & \multicolumn{2}{|c|}{$\begin{array}{l}\text { Masing-masing praktikum yang dibuka telah } \\
\text { memiliki RPS dan modul praktikum }\end{array}$} \\
\hline \multicolumn{2}{|c|}{ Assumptions : } & \multicolumn{2}{|c|}{$\begin{array}{l}\text { Masing-masing praktikum sudah ditetapkan dosen } \\
\text { pengampunya }\end{array}$} \\
\hline \multicolumn{2}{|c|}{ Requirement met : } & \multicolumn{2}{|c|}{$\begin{array}{l}\text { Dosen pengampu membuat RPS dan modul } \\
\text { praktikum }\end{array}$} \\
\hline \multicolumn{4}{|c|}{$\begin{array}{l}\text { Outstanding issues } \\
:\end{array}$} \\
\hline \multicolumn{2}{|c|}{ Priority : } & \multicolumn{2}{|l|}{ High } \\
\hline \multicolumn{2}{|c|}{ Risk : } & \multicolumn{2}{|l|}{ High } \\
\hline
\end{tabular}

Untuk activity diagram dari proses setup praktikum disajikan pada gambar 1 .

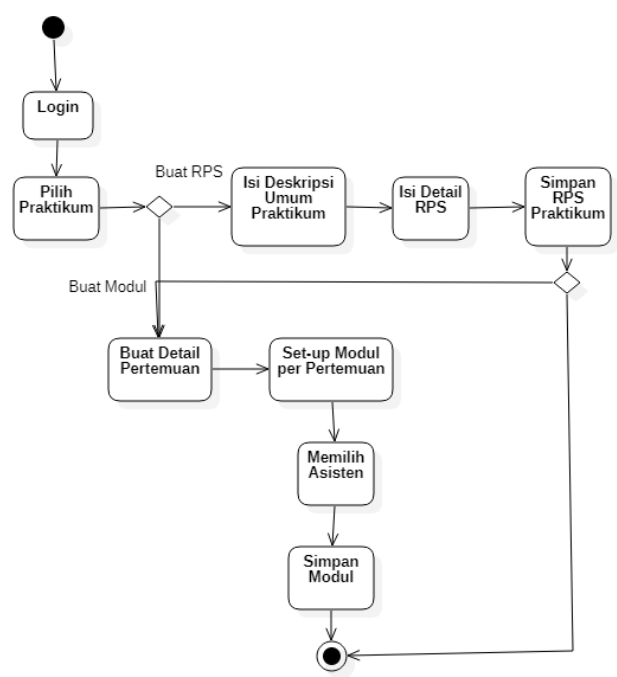

Gambar 1. Activity Diagram Setup

Praktikum

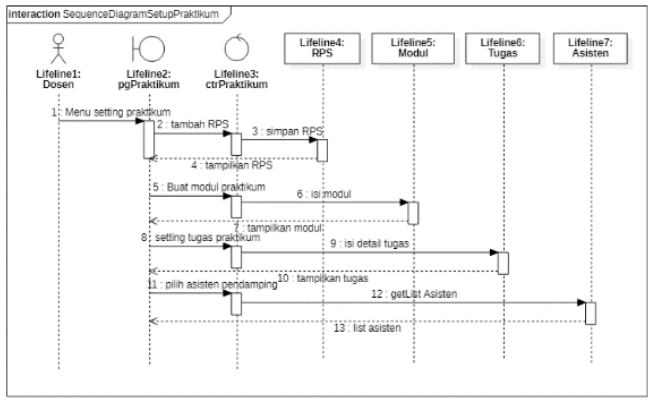

\section{Gambar 2. Sequence Diagram Setup} Praktikum

Scenario pembuatan jadwal praktikum disajikan pada tabel 2 .

Tabel 2. Skenario Pembuatan Jadwal

\begin{tabular}{|c|c|c|c|}
\hline \multirow{2}{*}{\multicolumn{2}{|c|}{$\begin{array}{l}\text { Use case name : } \\
\text { Area : }\end{array}$}} & \multicolumn{2}{|l|}{ Buat jadwal praktikum } \\
\hline & & \multicolumn{2}{|l|}{ SITRANS } \\
\hline \multicolumn{2}{|c|}{ Actor(s) : } & \multicolumn{2}{|l|}{ KaLab } \\
\hline \multicolumn{2}{|c|}{ Description : } & \multicolumn{2}{|c|}{$\begin{array}{l}\text { Membuat jadwal pelaksanaan praktikum yang dilaksanakan } \\
\text { oleh laboratorium }\end{array}$} \\
\hline \multicolumn{2}{|c|}{ Triggering Event } & \multicolumn{2}{|c|}{ Awal semester } \\
\hline \multicolumn{2}{|c|}{ Trigger Type: } & External & Temporal \\
\hline & Information for Steps \\
\hline \multicolumn{3}{|c|}{$\begin{array}{l}\text { Step Performed (Main Path) } \\
\text { 1. } \quad \text { KaLab login pada sub system praktikum }\end{array}$} & $\begin{array}{l}\text { Username, password, hak akses } \\
\text { KaLab }\end{array}$ \\
\hline 2. & \multicolumn{2}{|c|}{$\begin{array}{l}\text { KaLab melihat jumlah data peserta per } \\
\text { kelas }\end{array}$} & Data peserta praktikum per kelas \\
\hline 3. & \multicolumn{2}{|c|}{ KaLab membagi sessi praktikum } & $\begin{array}{l}\text { Data peserta praktikum, kapasitas } \\
\text { laboratorium }\end{array}$ \\
\hline 4. & \multicolumn{2}{|c|}{$\begin{array}{l}\text { KaLab membagi peserta praktikum } \\
\text { sesuai dengan sessi yang tersedia }\end{array}$} & Data sessi praktikum \\
\hline 5. & \multicolumn{2}{|c|}{$\begin{array}{l}\text { KaLab membuat jadwal sessi per modul } \\
\text { praktikum berdasarkan waktu serta } \\
\text { asisten yang tersedia }\end{array}$} & Data sessi, asisten \\
\hline 6. & \multicolumn{2}{|c|}{$\begin{array}{l}\text { System memeriksa ketersediaan jadwal } \\
\text { praktikum }\end{array}$} & Data jadwal praktikum \\
\hline \multicolumn{2}{|c|}{ Preconditions: } & \multicolumn{2}{|c|}{$\begin{array}{l}\text { Data peserta praktikum yang dibuka pada semester berjalan } \\
\text { telah ditetapkan }\end{array}$} \\
\hline \multicolumn{2}{|c|}{ Postconditions : } & \multicolumn{2}{|c|}{ Jadwal praktikum per sessi per modul tersedia } \\
\hline \multicolumn{2}{|c|}{ Assumptions : } & \multicolumn{2}{|c|}{$\begin{array}{l}\text { Masing-masing praktikum sudah ditetapkan dosen } \\
\text { pengampunya }\end{array}$} \\
\hline \multicolumn{2}{|c|}{ Requirement met } & \multicolumn{2}{|c|}{ Dosen pengampu membuat RPS dan modul praktikum } \\
\hline \multicolumn{4}{|c|}{ Outstanding issues : } \\
\hline \multicolumn{2}{|c|}{ Priority : } & \multicolumn{2}{|l|}{ High } \\
\hline \multicolumn{2}{|c|}{ Risk: } & \multicolumn{2}{|l|}{ High } \\
\hline
\end{tabular}

Selanjutnya dibuat activity diagram untuk pembuatan jadwal seperti gambar 3 . 


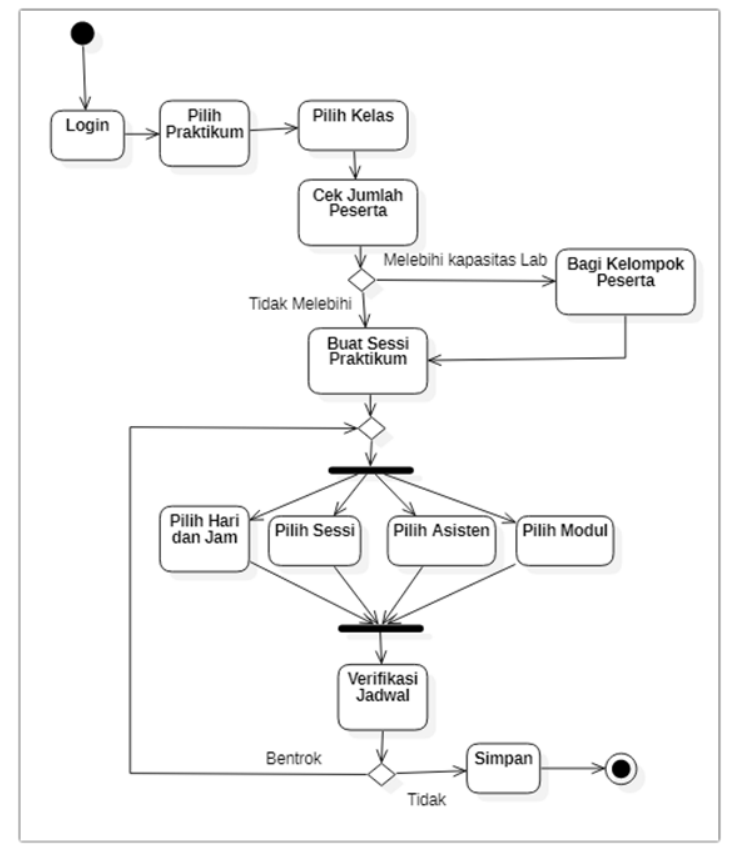

Gambar 3 Activity Diagram Pembuatan Jadwal

Sequence diagram dibuat seperti gambar 4 untuk menggambarkan interaksi antar obyek.

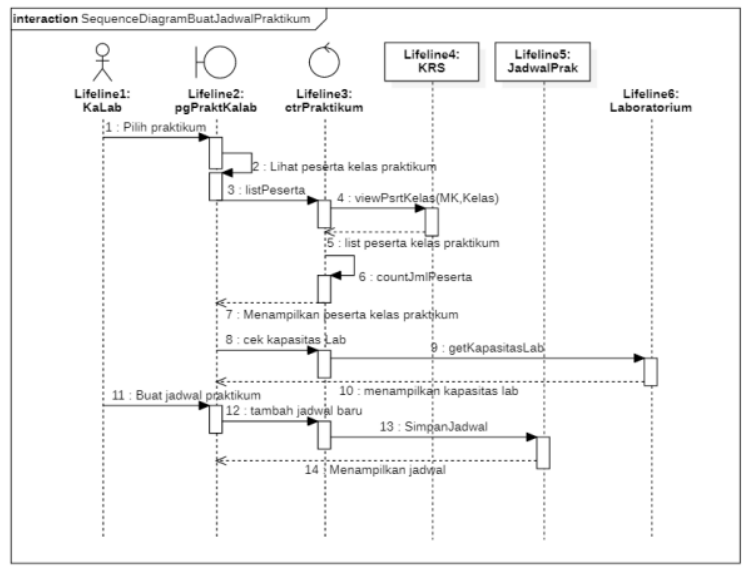

Gambar 4. Sequence Diagram Pembuatan Jadwal

\subsection{Pelaksanaan Praktikum}

Bagian ini meliputi dua proses yaitu monitoring dan entry nilai praktikum.

Tabel 3. Skenario Monitoring Praktikum

Use case name : Monitoring Praktikum $\quad$ UniqueID :

\begin{tabular}{|c|c|c|c|}
\hline \multirow{2}{*}{\multicolumn{2}{|c|}{$\begin{array}{l}\text { Area : } \\
\text { Actor(s) : }\end{array}$}} & \multirow{2}{*}{\multicolumn{2}{|c|}{ SITRANS }} \\
\hline & & & \\
\hline \multicolumn{2}{|c|}{ Description: } & \multicolumn{2}{|c|}{$\begin{array}{l}\text { Monitoring pelaksanaan praktikum yang meliputi, presensi } \\
\text { kehadiran mahasiswa dalam praktikum, pengerjaan dan } \\
\text { pengumpulan tugas per modul, bimbingan dan penilaian } \\
\text { asisten terhadap laporan hasil praktikum, serta rekapitulasi } \\
\text { nilai praktikum mahasiswa di akhir semester }\end{array}$} \\
\hline \multicolumn{2}{|c|}{ Triggering Event } & \multicolumn{2}{|c|}{ Pelaksanaan praktikum } \\
\hline \multirow{2}{*}{\multicolumn{3}{|c|}{$\begin{array}{ll}\text { Trigger Type : } & \text { External } \\
\text { Step Performed (Main Path) } & \\
\end{array}$}} & Temporal \\
\hline & & & Information for Steps \\
\hline 1. & \multicolumn{2}{|c|}{$\begin{array}{l}\text { Mahasiswa login pada sub system } \\
\text { praktikum }\end{array}$} & $\begin{array}{l}\text { Username, password, hak akses } \\
\text { mahasiswa }\end{array}$ \\
\hline 2. & \multicolumn{2}{|c|}{$\begin{array}{l}\text { Mahasiswa melihat praktikum yang } \\
\text { diikuti }\end{array}$} & Data praktikum yang diikuti \\
\hline 3. & \multicolumn{2}{|c|}{ Mahasiswa mengisi presensi kehadiran } & Data sessi \\
\hline 4. & \multicolumn{2}{|c|}{$\begin{array}{l}\text { Mahasiswa mengerjakan tugas modul } \\
\text { yang diberikan }\end{array}$} & Data modul \\
\hline 5. & \multicolumn{2}{|c|}{$\begin{array}{l}\text { Mahasiswa mengumpulkan tugas dan } \\
\text { laporan hasil praktikum }\end{array}$} & Data tugas modul \\
\hline 6. & \multicolumn{2}{|c|}{$\begin{array}{l}\text { Asisten memeriksa laporan hasil } \\
\text { praktikum dan memberikan nilai }\end{array}$} & Data laporan hasil praktikum \\
\hline 7. & \multicolumn{2}{|c|}{$\begin{array}{l}\text { Dosen memeriksa tugas, laporan hasil } \\
\text { praktikum serta penilaian dari asisten }\end{array}$} & Data laporan hasil praktikum, nilai \\
\hline 8. & \multicolumn{2}{|c|}{$\begin{array}{l}\text { Dosen melakukan rekapitulasi nilai } \\
\text { praktikum mahasiswa }\end{array}$} & Data nilai \\
\hline 9. & \multicolumn{2}{|c|}{$\begin{array}{l}\text { Dosen membuat laporan nilai } \\
\text { praktikum }\end{array}$} & Data nilai \\
\hline \multicolumn{2}{|c|}{ Preconditions: } & \multicolumn{2}{|c|}{ Pelaksanaan praktikum } \\
\hline \multicolumn{2}{|c|}{ Postconditions : } & \multicolumn{2}{|c|}{ Mahasiswa mendapatkan nilai dari praktikum yang diikuti } \\
\hline \multicolumn{2}{|c|}{ Assumptions : } & \multicolumn{2}{|c|}{$\begin{array}{l}\text { Mahasiswa mengikuti kegiatan praktikum dari awal sampai } \\
\text { akhir }\end{array}$} \\
\hline \multicolumn{2}{|c|}{ Requirement met } & \multicolumn{2}{|c|}{ Dokumentasi kegiatan praktikum tercatat dengan baik } \\
\hline \multicolumn{4}{|c|}{ Outstanding issues : } \\
\hline \multicolumn{2}{|c|}{ Priority: } & \multicolumn{2}{|l|}{ High } \\
\hline \multicolumn{2}{|c|}{ Risk : } & \multicolumn{2}{|l|}{ High } \\
\hline
\end{tabular}

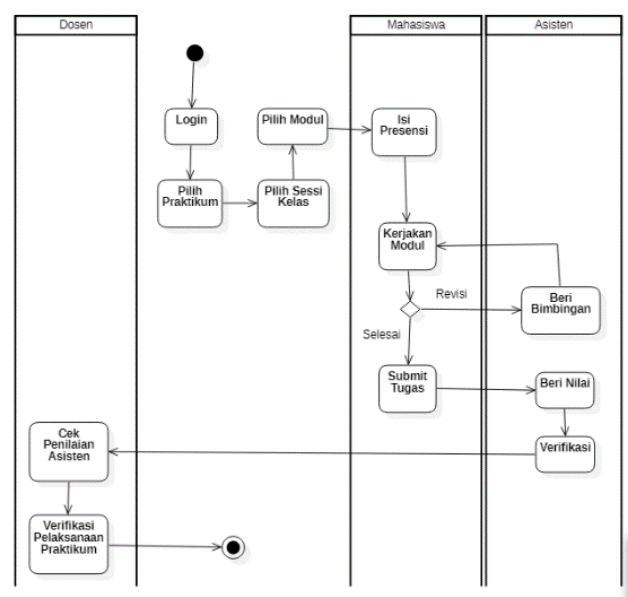

Gambar 5 Activity Diagram Monitoring Praktikum

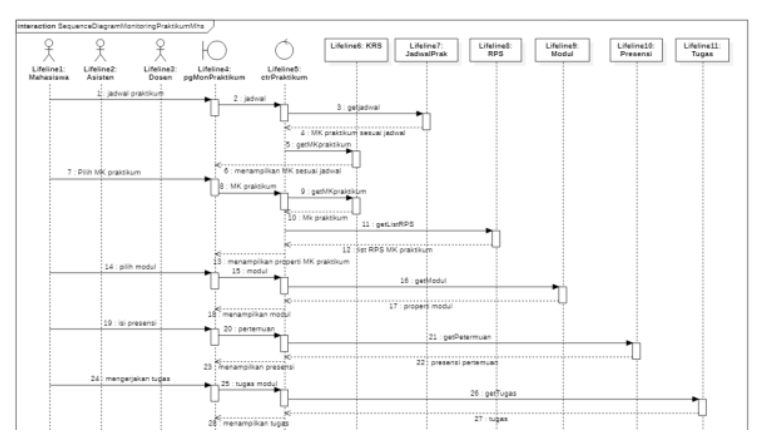




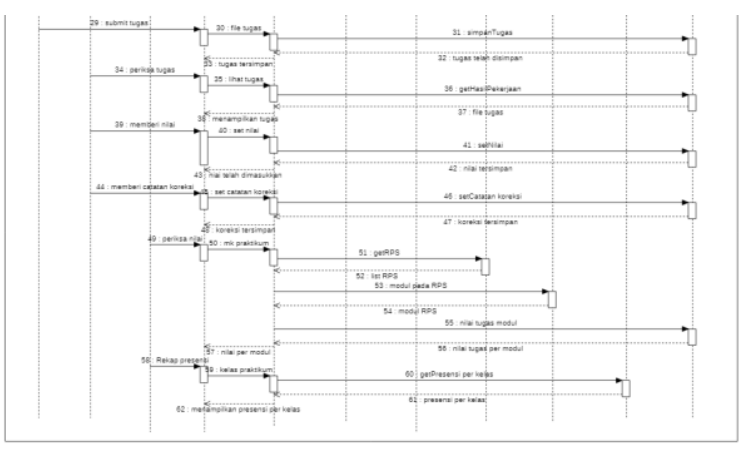

Gambar 6. Sequence Diagram Monitoring Praktikum

Tabel 4. Skenario Entry Nilai

\begin{tabular}{|c|c|c|c|}
\hline \multirow{2}{*}{\multicolumn{2}{|c|}{$\begin{array}{l}\text { Use case name : } \\
\text { Area : }\end{array}$}} & \multicolumn{2}{|l|}{ Entry Nilai } \\
\hline & & \multicolumn{2}{|l|}{ SITRANS } \\
\hline \multicolumn{2}{|c|}{ Actor(s) : } & \multicolumn{2}{|l|}{ Asisten, dosen } \\
\hline \multicolumn{2}{|c|}{ Description : } & \multicolumn{2}{|c|}{$\begin{array}{l}\text { Entry nilai merupakan bagian dari proses monitoring } \\
\text { pelaksanaan praktikum, dimana Asisten memberikan } \\
\text { penilaian terhadap hasil perkerjaan mahasiswa dalam } \\
\text { menyelesaian tugas modul praktikum serta penilaian } \\
\text { akhir praktikum yang diberikan dosen berdasarkan } \\
\text { rekapitulasi nilai yang diperoleh mahasiswa. }\end{array}$} \\
\hline \multicolumn{2}{|c|}{ Triggering Event : } & \multicolumn{2}{|c|}{ Penyelesaian tugas modul praktikum } \\
\hline \multicolumn{2}{|c|}{ Trigger Type : } & External & Temporal \\
\hline \multicolumn{3}{|c|}{ Step Performed (Main Path) } & Information for Steps \\
\hline 1. & \multicolumn{2}{|c|}{$\begin{array}{l}\text { Asisten login pada sub system } \\
\text { praktikum }\end{array}$} & $\begin{array}{l}\text { Username, password, hak akses } \\
\text { Asisten }\end{array}$ \\
\hline 2. & \multicolumn{2}{|c|}{$\begin{array}{l}\text { Asisten memeriksa hasil penyelesaian } \\
\text { tugas modul mahasiswa }\end{array}$} & $\begin{array}{l}\text { Data file tugas modul } \\
\text { mahasiswa }\end{array}$ \\
\hline 3. & \multicolumn{2}{|c|}{ Asisten memberi nilai } & $\begin{array}{l}\text { Data file tugas modul } \\
\text { mahasiswa }\end{array}$ \\
\hline 4. & \multicolumn{2}{|c|}{$\begin{array}{l}\text { Asisten memberikan catatan koreksi, } \\
\text { bila ada yang harus diperbaiki } \\
\text { mahasiswa. Setelah mahasiswa } \\
\text { merevisi tugasnya, Asisten } \\
\text { memberikan nilai kembali }\end{array}$} & Data catatan koreksi \\
\hline 5. & \multicolumn{2}{|c|}{$\begin{array}{l}\text { Dosen melihat nilai yang telah } \\
\text { diberikan asisten dan melihat tugas } \\
\text { mahasiswa }\end{array}$} & Data nilai tugas modul \\
\hline 6. & \multicolumn{2}{|c|}{$\begin{array}{l}\text { Di akhir semester, Dosen melihat } \\
\text { seluruh nilai tugas mahasiswa pada } \\
\text { setiap modul }\end{array}$} & $\begin{array}{l}\text { Data list nilai tugas semua } \\
\text { modul }\end{array}$ \\
\hline 7. & \multicolumn{2}{|c|}{$\begin{array}{l}\text { Dosen melakukan rekapitulasi dan } \\
\text { memberikan nilai akhir praktikum }\end{array}$} & Data list nilai \\
\hline \multicolumn{2}{|c|}{ Preconditions : } & \multicolumn{2}{|c|}{ Mahasiswa telah menyelesaikan tugas modul } \\
\hline \multicolumn{2}{|c|}{ Postconditions : } & \multicolumn{2}{|c|}{$\begin{array}{l}\text { Mahasiswa mendapatkan nilai setiap tugas dan nilai } \\
\text { akhir praktikum }\end{array}$} \\
\hline \multicolumn{2}{|c|}{ Assumptions : } & \multicolumn{2}{|c|}{ Mahasiswa menyelesaikan tugas setiap modul } \\
\hline \multicolumn{2}{|c|}{ Requirement met : } & \multicolumn{2}{|c|}{ Asisten memberikan penilaian untuk setiap tugas } \\
\hline \multicolumn{4}{|c|}{ Outstanding issues : } \\
\hline \multicolumn{2}{|c|}{ Priority: } & \multicolumn{2}{|l|}{ High } \\
\hline \multicolumn{2}{|c|}{ Risk : } & \multicolumn{2}{|l|}{ High } \\
\hline
\end{tabular}

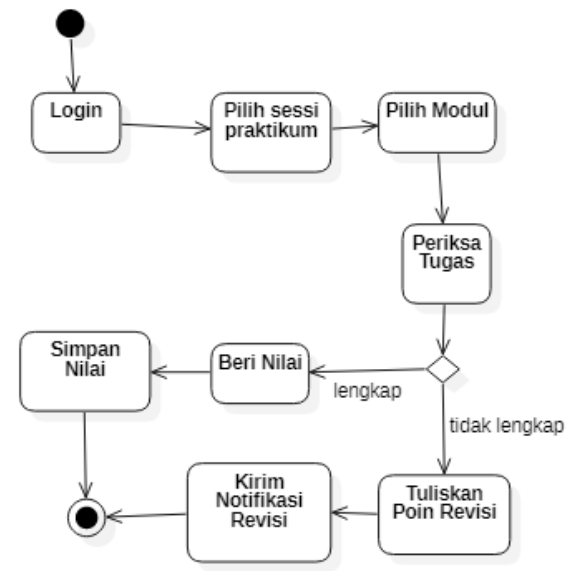

Gambar 7. Activity Diagram Entry Nilai

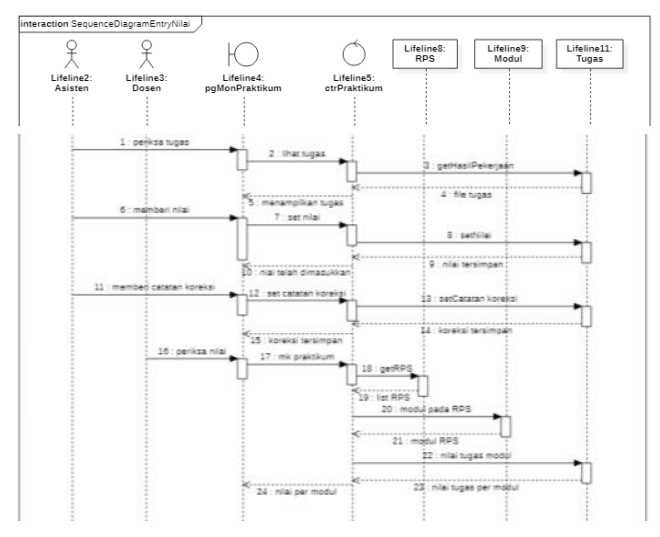

Gambar 8. Sequence Diagram Entry Nilai

\subsection{Class Diagram}

Untuk memberikan gambaran mengenai sistem yang diusulkan beserta relasi yang terdapat pada sistem tersebut maka penulis membuat sebuah class diagram untuk modul praktikum dan tugas seperti gambar 9 . 


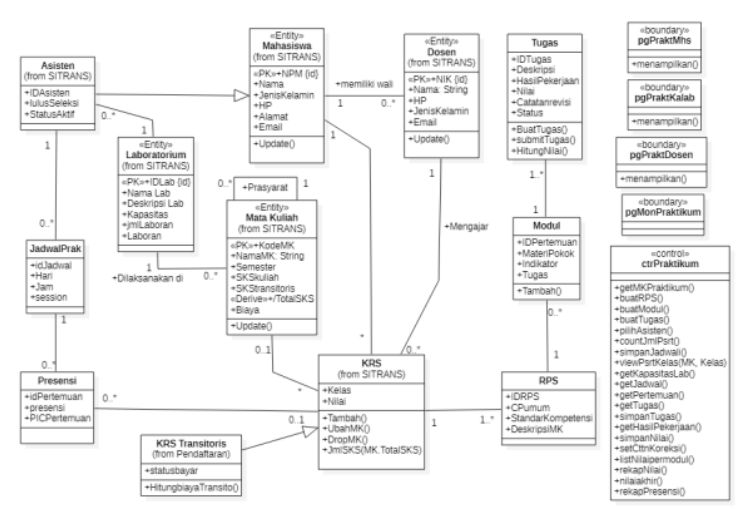

Gambar 9. Class Diagram Praktikum Dan Tugas

\section{Kesimpulan}

Berdasarkan hasil penelitian dan pembahasan, dapat disimpulkan beberapa hal antara lain perancangan sistem manajemen lab yang dihasilkan mencakup pengelolaan kegiatan praktikum saja. Kegiatan praktikum yang dimaksud meliputi perencanaan yaitu setup praktikum dan pembuatan jadwal, sedangkan pelaksanaan terdiri dari monitoring kegiatan praktikum dan entry nilai hasil praktikum. Hasil perancangan menggunakan pemodelan UML berupa use case scenario, activity diagram dan sequence diagram yang dapat memberikan gambaran teknis dan logis bagi pengembangan sistem berikutnya. Class diagram dihasilkan sebagai dasar perancangan basis data dan relasinya.

\section{DAFTAR PUSTAKA}

Badan Pengembangan dan Pembinaan Bahasa Kemdikbud RI. (2016). Kamus Besar Bahasa Indonesia. Jakarta.

Booch, G., Rumbaugh, j., \& Jacobson, I. (2005). The Unified Modeling Language User Guide. New York: Addison Wesley.

Ibrahim, B. (2003). Manajemen

Perlengkapan Sekolah Teori dan
Aplikasinya. Jakarta: PT Bumi Aksara.

Lunetta, V. N., Hofstein, A., \& Clough, M. P. (2007). Teaching and learning in the school science laboratory. An analysis of research, theory and practice.

Nugroho, A. (2009). Rekayasa Perangkat Lunak Menggunakan UML Dan Java. Yogyakarta: ANDI .

Nugroho, A. (2010). Rekayasa Perangkat Lunak Berbasis Objek dengan Metode USDP. Yogyakarta: ANDI.

Putra, D. W., \& Andriani, R. (2019). Unified Modelling Language (UML) dalam Perancangan Sisteml nformasi Permohonan Pembayaran Restitusi SPPD. TEKNOIF, 7(1), 32-39.

Satzinger, J. W., Jackson, R. B., \& Burd, S. D. (2011). Systems Analysis and Design in a Changing World, Sixth ed.

Soedirman, D. W. (2011). Pengelolaan Laboratorium Pendidikan Administrasi Perkantoran. Efisiensi, $X I(2), 56-65$.

Supianto, A. (2016). PENGELOLAAN LABORATORIUM KOMPUTER. Manajer Pendidikan, 10(6), 559571.

Winataputra, U. S. (2007). Teori Belajar dan Pembelajaran. Jakarta.

Yanuarti, E. (2017). Desain Aplikasi Pengelolaan Laboratorium Komputer. SISFOKOM, 6(1), 60-66.

Zain, D. d. (2006). Strategi Belajar Mengajar. Jakarta: Rineka. 